\title{
ACCESS TO JUSTICE AND ABUSES OF CONTRACT
}

\section{Margaret Jane Radin*}

Mass-market standardized fine print (boilerplate) altering the rights of consumers is greatly expanding in today's digital environment Mass-market boilerplate impacts access to justice when it deletes rights to redress of grievances. Such deletion of rights leads to normative degradation because it undermines agreement, which is the basis of justifiable contractual enforcement, and leads to democratic degradation because it undermines the basis of civil society and the rule of law. A brief comparison of US and Canadian common law suggests that Canada's legal system is less willing to allow these inroads into access to justice.

Dans le monde numérique d'aujourd'hui, l'insertion dans les conventions, ententes et contrats les plus communs de clauses standardisées en petits caractères, qui dénaturent les droits des consommateurs, est de plus en plus fréquente. Ces clauses passe-partout ont des répercussions sur l'accès à la justice lorsqu'elles suppriment le droit à la réparation d'un préjudice. Une telle suppression de droits mène à la dégradation normative parce qu'elle mine le consentement, qui est la base de l'exécution justifiable d'une obligation contractuelle, et à la dégradation de la démocratie parce qu'elle gruge la base de la société civile et la primauté du droit. Une brève comparaison de la common law des États-Unis et de celle du Canada laisse voir que le système juridique canadien est moins porté à permettre de tels empiètements sur l'accès à la justice.

\section{INTRODUCTION: CONTRACT IN THE INFORMATION SOCIETY}

In the contemporary world, at least in developed countries, we are inundated with, and surrounded by, information. We are governed by information that we cannot see; that if we did see, we could not understand; and that if we did see and did understand, we could not do anything to alter. Information relating to us is internal to vast systems of computer hard drives or offered to us in reams of indecipherable fine print. I do not mean to say that this situation is completely pervasive, engulfing all activities and understandings by individuals. There still exist fully negotiated contracts between equals and financial and medical disclosures and advice that recipients can understand. But mass governance by information that we do not see and cannot manage is widespread today in a way that has never happened before. This situation has prompted the coinage of the term "information society" for the circumstances under which we live.

The burgeoning of the information society has many repercussions for access to justice. Among them are the activities of the surveillance state and the issues raised for individual privacy; the activities of the

Faculty of Law Distinguished Fellow, University of Toronto; Henry King Ransom Professor of Law, emerita, University of Michigan; William Benjamin Scott and Luna M Scott Professor of Law, emerita, Stanford University. Thanks to Dean Camille Cameron and Pascale Chapdelaine of the University of Windsor's Faculty of Law for inviting me to lecture on the topic that is the basis of this article. 
regulatory state and the issues raised for individual freedom and safety; the role of multinational enterprises in superseding the jurisprudential safeguards of nation states; and the issues their role raises for justice and economic well-being. Broadly construed, all of these developments pose issues for the viability of the rule of law, of which appropriate access to justice is a prime feature. In this article, I do not attempt to survey various aspects of the information society and their impact on access to justice but, rather, will confine my consideration to some problems in contract law. We are seeing the burgeoning of the information society in the use of contracts, especially in the use of contract law to enforce documents called contracts that do not fit the traditional basis and justification of actual contracts. In what follows, I will sometimes place the word "contracts" in quotation marks to express my view that things called "contracts" in today's world often do not fit the theory of contract formation and the justification for contract enforcement.

Consider the example of the new terms of service promulgated by Facebook in January 2015. Many readers of this article, perhaps a large majority, are users of Facebook. But very few users know that new terms were imposed, and fewer have read them. Fewer still have disconnected from Facebook because they wished to escape being subjected to the new terms. If someone did read the terms ${ }^{1}$ and wished to disconnect and delete her account, she would discover that certain things will nevertheless stay in Facebook's power: Facebook says it will delete information associated with your account, but not if it still needs the data to provide products and services. Moreover, even if you delete your account, information that others have shared about you will not be deleted. In other words, Facebook will continue to feature your stories and photos in advertisements. You are deemed to "agree" to Facebook's terms by having continued to use Facebook after 1 January 2015. But if you disagreed, and wanted to stop using its services to avoid being subject to its terms, they say you cannot, at least not fully. Facebook has gradually broadened its terms over time. During this time, many people have grown up with their entire life history on Facebook. They cannot delete their accounts without pain. And even if they do, the possibility of using their content for marketing remains.

Does Facebook's terms of service [TOS], in its totality, amount to a contract with the user? Facebook refers to it as a "policy" that "took effect" on 1 January 2015. If this is a contract, it lacks certain criteria that lawyers and law students know from contract theory and learn in our first year of law school. Facebook's TOS does not have the indicia of an agreement voluntarily entered into by both Facebook and the user, because the user does not know what the terms are or how those terms will affect him or her.

Lawyers and law students will know, of course, that contemporary contract law uses a particular doctrine to say that if a recipient should have noticed the terms, then it will be held that the situation is "as if" the recipient had notice of the terms, and such as-if notice will be treated as if it were consent by the recipient. If we wish to protest the enforcement of such a "contract," we are shunted to arguing that notice was lacking (or to some other defence against contractual formation, such as unconscionability.) But to my way of thinking, this double as-if [as-if notice = as-if consent] is an unsatisfactory way to create legal obligation. Despite its widespread use, I consider it a stop-gap, shoring up contract doctrine that is no longer suited for the society in which we live.

Unlike many purveyors of fine print terms of service, Facebook uses plain English. But Facebook makes it very hard to find the terms - they are spread out among different pages that the user would have to click to see. 


\section{NORMATIVE DEGRADATION AND FINE PRINT AS A DEFECTIVE PRODUCT}

\section{A. Contemporary Normative Degradation}

I use the term "normative degradation" to refer to instances where the normative rationale for contract enforcement - that is, agreement between two willing parties - has been stretched beyond the breaking point. The Facebook TOS is an instance of normative degradation. Normative degradation has vastly increased in the information society due to the computerization of so many ordinary transactions that used to be done in person. Buying online involves boilerplate terms, whereas buying in a store does not.

Moreover, boilerplate terms can be copied with ease from transaction to transaction and from firm to firm by simply pushing a key on a computer, so copycat boilerplate proliferates. (I have known law students whose summer jobs involved copying boilerplate terms from others.) It is true, as I will mention later, that legal technology, including standardized contracts, can be used for risk management. But the copycat phenomenon belies any claim that mass-market boilerplate waivers are the result of thoughtful attempts at risk management by each particular firm. And, perhaps surprisingly, it appears that copycat boilerplate is not only endemic to consumer transactions but also used in transactions between sophisticated players. ${ }^{2}$

In spite of the prevalence of normative degradation in the "contracts" enforced today, at least in the United States, many observers say that we cannot help this situation because standardization is very important to our contemporary economy, and we need to leave standardization unfettered. ${ }^{3}$ I will pause here to make clear that I am not arguing against standardization. Standardization came to us with industrialization. It is here to stay. It is a good thing that spare parts are standardized and ready at hand. No one wants to go back to the situation that gave rise to the problems in Hadley $v$ Baxendale, where a spare part (a replacement mill shaft) had to be constructed to order by hand. ${ }^{4}$ With the standardization of products of all kinds, from axes to automobiles, from zippers to zwiebacks, came the standardization of contracts, beginning with insurance policies and spreading throughout the economy. Of course, we still want to have products made to order when we choose and can afford them - we may prefer nonstandardized slow food to standardized fast food, for example - but no one wants to go back to a pervasive non-standardized economy, which cannot be recovered in any case.

The standardization of terms and procedures might be considered the technology of law since the standardization of products and their components is the technology of production. In many ways, the technology of law is useful, often indispensable. For example, vast numbers of documents can now be scanned and information sorted in ways that humans could not accomplish. Thus, procedure and evidence law and practice have undergone technological revolutions. Yet the standardization of

2 Mitu Gulati \& Robert E Scott, The 3-1/2 Minute Transaction: Boilerplate and the Limits of Contract Design (Chicago: University of Chicago Press, 2012) (a "sticky" boilerplate clause keeps reappearing in sovereign bond contracts even though specialist law firms and underwriters believe it is wrong and has created bad precedent).

3 See, eg, Omri Ben-Shahar, "The Myth of the 'Opportunity to Read' in Contract Law" (2009) 5:1 European Review of Contract Law 1; Brian H Bix, "Contracts" in Franklin G Miller \& Alan Wertheimer, eds, The Ethics of Consent (New York: Oxford University Press, 2010) 251.

4 (1854) 9 Exch 341, (1854) 156 ER 145 
contracts carries with it issues that are not present, or at least not pervasively present, in the computerization of other fields of law or the standardization of products, whether tangible or intangible. It is possible to buy a product without any accompanying boilerplate, of course, as we do every day in the grocery store and many other places, and if a contractual dispute arises, it will be decided under the public background rules for contract formation and remedies. Boilerplate deployed by firms is used primarily for the purpose of altering the background rules that would otherwise govern contract enforcement and remedies. This was already done in the pre-Internet society, but it has become extraordinarily easier to do this in the online environment. That is, it is now very easy to opt out of the rules of the state and into the firm's own rule structure, which is designed for the firm's own benefit most of the time. All one needs to do is click "I agree."

The question arises: how much should we allow this contemporary technology of law to withdraw the background rules of law? Of course, private law allows parties to contract out of various aspects of background contract law. Freedom of contract is a firm underlying concept of the liberal state. For example, firms may contract with each other to waive liability for one of the parties, with the intended result of making it the responsibility of the other party to acquire insurance or to self-insure. When firms negotiate such deals, it is likely that the party who is the best cost-avoider will take on the risk because it is outweighed by gains in other provisions of the contract.

Yet there are some aspects of contract law that not even willing and cognizant parties can contract out of, especially the duty that is variously conceptualized as good faith, fair dealing, or honesty in performance. ${ }^{5}$ The question arises whether the onset of the mass-market boilerplate should motivate us to take another look at what background rules can or cannot be waived, and I consider this important issue later in this article. ${ }^{6}$

\section{B. Normative Degradation and Defective Products}

Meanwhile, consider a popular "Chicago" way of looking at mass-market boilerplate that has been advanced by Douglas Baird. ${ }^{7}$ Baird assumes, following the principles of what I call old-school Chicago

5 The way in which such an ethical duty is characterized varies from jurisdiction to jurisdiction, and there is controversy within jurisdictions and in scholarly attempts to explain the concept. In Canada, the Supreme Court of Canada has declared that good faith is a common law organizing principle resulting in a contractual duty of honest performance, which is non-waivable by the parties but whose specific requirements will vary with the particular contract under consideration. Bhasin v Hrynew, 2014 SCC 71 (2014). For disputed understanding in the United States, compare, eg, Robert S Summers, "The General Duty of Good Faith: Its Recognition and Conceptualization" (1982) 67 Cornell L Rev 810 with Steven J Burton, "Breach of Contract and the Common Law Duty to Perform in Good Faith" (1980) 94 Harv L Rev 369. It should be acknowledged that the concept of good faith is vague and malleable. But it should also be acknowledged that if it were to be allowed that contractual parties may act in bad faith or dishonestly - even if their contract has a clause permitting them to act in bad faith or dishonestly - trust in the system of contract would erode, and, thus, its utility to participants would erode. Hence, the duty of good faith, fair dealing, or honesty, whatever its contours, cannot be freely waivable by the parties. See, eg, Charles Fried, Contract as Promise: A Theory of Contractual Obligation, 2nd edition (New York: Oxford University Press 2015).

6 The most troublesome clauses are blanket exclusion (exculpatory) clauses, mandatory pre-dispute arbitration clauses, and remote choice of forum clauses. For discussion, see Section III.

7 Douglas G Baird, "The Boilerplate Puzzle" (2006) 104 Mich L Rev 933, as reprinted in Omri Ben-Shahar, ed, Boilerplate: The Foundation of Market Contract (New York: Cambridge University Press, 2007) 131; Douglas G Baird, Reconstructing Contracts (Cambridge, MA: Harvard University Press, 2013) 124-127. 
law and economics, ${ }^{8}$ that a sufficient number of consumers will use rationality to assess the value of a product, and their demand level will set the market price for everyone else, even those who are not rational in this old-school economic sense. Moreover, Baird expands the definition of a product. He suggests that the fine print that accompanies a physical product is no different from the other, more physical, attributes of a product. ${ }^{9}$ (Indeed, often the product and the fine print are both digital, such as software that comes with an end user license agreement (EULA)). The rational subset of consumers wishing to purchase either a physical product or a digital product will consider the effect of the fine print along with the effect of the substantive attributes of the device or program. In buying a computer, for example, rational consumers will consider the effect of the fine print along with the effect of the battery rating and the design of the screen in deciding the price they are willing to pay, and this rationality will set the market price.

Given the extent of normative degradation, there is a certain appeal to the idea of fine print not being a "contract" but, rather, being part of a product. (I will refer to this idea as the "expanded product theory.") Most consumer buyers do not know what is inside the physical product and also do not know what the fine print says or what it means. Thus, this theory has a certain refreshing connection with contemporary reality. It also has various unrealistic aspects, however. One unrealistic aspect is that this rational approach assumes a competitive market (and many consumer markets are not competitive). Another unrealistic aspect is the assumption that there will be a savvy subset of consumers who bring economic rationality to bear on their demand for the [physical-plus-fine-print] product. $^{10}$

A further unrealistic - or at least unattractive - aspect of the expanded product theory, as explained by Baird, is this theory's apparent lack of focus on the fact that a product can be defective. When a product is defective, its purveyor is subject to liability for that reason, usually as a matter of tort law. It may be realistic in the contemporary mass market world to consider standardized fine print accompanying a standardized physical product as being subject to market forces without looking for oldfashioned individual consent, as the expanded product theory does, but there must still be a limit on what clauses can be used without rendering the product defective. The normative degradation resulting from the over-expansion of the contract does not go away if we allow the very same boilerplate to be exonerated by being treated as part of the defective product.

As I mentioned, market failures can render inapposite the nice story told by the expanded product theory as put forward by Baird. The fine print embedded in a composite product may be deployed in a non-competitive market or in a market in which too many consumers lack information about the product - a situation that leads to a race to the bottom. If consumers do not have the information needed to evaluate a product (a situation known as information asymmetry because the firms themselves have the

8 By old school Chicago law and economics, I refer to a set of premises based upon the assumed rationality of actors, among other assumptions. For my list of premises of old school Chicago law and economics, see Margaret Jane Radin, “Of Priors and Disconnects: How 'Chicago' Premises Risk Distortion” (2014) 127 Harvard L Rev Forum 259 at 261. I also laid out my view of the premises of that style of law and economics in chapter 4 of my book, Margaret Jane Radin, Boilerplate: The Fine Print, Vanishing Rights, and the Rule of Law (Princeton: Princeton University Press, 2013) at 6366.

9 The idea of contract terms as part of a product seems to have originated with Arthur Allen Leff, "Contract as Thing" (1970) 19 Am U L Rev 131.

10 But see Yanos Bakos, Florencia Marotta-Wurgler \& David R Trossen, "Does Anyone Read the Fine Print? Consumer Attention to Standard Form Contracts" (2014) 43 J Leg Stud 1. 
information about their products), firms can either lower the quality without lowering the price or lower the price and lower the quality more. When this happens, firms that do not lower the quality will receive lower revenues and perhaps be driven out of the market.

As a society, we might decide to leave these matters to antitrust law or other forms of competition law, or we might decide to have regulatory agencies of various kinds act as watchdogs. But to elucidate the analogy between bad boilerplate and defective products, assume for a moment that society does not have regulatory laws regarding food products. Consider a consumer who is purchasing a package of meat in the grocery store. Suppose the package has a label on it saying that it is purchased at the consumer's risk. It may say something like: "By purchasing this package you agree that neither the seller nor the producer are liable for any disease or other harm caused by spoilage or contamination." If there were such a clause, it would be difficult to use contract law to disallow it because the consumer has purposely purchased the package and did have notice of the clause. Perhaps unconscionability would be applicable, but unconscionability is a wild card in the sense that it is adjudicated case by case. Even if a consumer wins, she is the only one; all of the other consumers who received the clause may be stuck with it or must try their luck in other courts that may rule differently. Moreover, the widespread usage of a particular clause is often a defence to unconscionability, as is a finding that the consumer had notice or "as-if" notice - of the clause. ${ }^{11}$

If we adopt the expanded product theory, it could be held that this exculpatory label is not a "contract" but, rather, a component of a defective product, namely contaminated meat plus bad fine print. Such a holding would have the preferable result of taking the defective product off the market for everyone. With this particular example, most of us probably believe that the regulation of food production and packaging by a governmental agency, complete with the sanction of compliance verification rules, would be better at preventing harm to consumers. The point of this example is that a label waiving basic background rules of legal redress - that is, a boilerplate "contract" - seems to be relevantly similar and should prompt us to consider avenues of relief other than the legal doctrines of contract to protect consumers.

There is still likely to be a choice between private law and public law (regulation) when we evaluate how to prevent or minimize harm to the populace. But in the era of mass-market standardization, if we are sticking to private law, the alternative of liability for defective products seems preferable to the fictional deployment of "contract." Probably the best result for keeping boilerplate within bounds will be some mix of the two - both judicial decisions and regulatory rules. With respect to regulatory rules, I should note that the European Union, since its 1993 Council Directive on Unfair Terms in Consumer Contracts, has disfavoured many of the problematic clauses I have mentioned, and these rules have gotten stricter over time as the rules have been approximated by the member states. ${ }^{12}$ In addition, in the United States, as elsewhere, there are many consumer protection laws, some on the federal level and a great many on the state level. The resulting patchwork of federal, state, and local laws is beyond the

See the conclusion of the first part of this article.

12 See, eg, Geraint Howells \& Reiner Schulze, eds, Modernising and Harmonising Consumer Contract Law (Munich: Sellier European Law Publishers 2009). EEC Directive on Unfair Terms in Consumer Contracts (1993) OJ L95; For discussion of problematic clauses, see Section III. 
scope of this article, ${ }^{13}$ but I note that federal agencies, at least, such as the US Federal Trade Commission, could declare certain clauses to be prima facie harmful to the public. It should certainly do so in the case of clauses that cause normative and democratic degradation by undermining the fundamental rights of civil society. (That it does not do so is a political, not a legal, problem.)

In sum, I am proposing that there can be defects other than physical defects. Specific terms can also render the composite product defective. A physical defect in a computer can cause it to explode and injure the user. At the same time, and analogously, any number of fine print clauses can also injure the user unexpectedly, unreasonably, or, in any event, in ways that a well-functioning civil society should disallow, just as it disallows contracting deceptively and unethically. Some of the clauses that may render an expanded product defective might be payment clauses that are deceptive in light of consumer reasoning characteristics that are divergent from the posited old school economic rationality. ${ }^{14}$ Such deceptive clauses would include, in context, balloon payments, sudden increases in interest payments, or high fees for bouncing a check. ${ }^{15}$ Other clauses might involve the kind of rights that must remain intact as part of the background rules of society such that to allow them to be waived - even with real consent, but a fortiori if there is not real consent - would undermine the basic premises of civil society. The undermining of these basic premises of polity leads to what I call democratic degradation.

\section{DEMOCRATIC DEGRADATION AND ACCESS TO JUSTICE}

Democratic degradation refers to a situation in which the liberal democratic state no longer performs the duties by which its existence and power are justified. Democratic degradation undermines the basic idea that the people in a liberal polity ultimately govern themselves through the proper administration of governance by the state. If public officials are bribed by powerful interests, it would result in democratic degradation. It would also be democratic degradation if citizens were harmed by government or if private wrongful acts were to have no avenue of redress.

In the quaint metaphor that characterizes the basis of liberal society, people exit the state of nature and form a state (polity) to protect them from predation by others and to provide goods that can only be achieved by coordination. Among the rules that must remain intact because of the basic premises of civil society are access-to-justice rules. None of the protections afforded by civil society could exist without remedies provided in case the protections are breached. Physical safety cannot be guaranteed without remedy available for anyone who suffers physical harm at the hands of another person or of the state (whether the remedy be private law, tort or public law, prevention, or compensation). Freedom of

13 See, eg, Jean Braucher, "Form and Substance in Consumer Financial Protection" (2012) 7 Brooklyn Journal of Corporate, Financial \& Consumer Law 107.

14 The behavioral economist Richard Thaler has called the non-existent being of traditional economics an "Econ." "Humans" do not reason the way "Econs" do. Richard H Thaler, Misbehaving: The Making of Behavioral Economics (New York: WW Norton \& Company, 2015). The research reported in Daniel Kahneman's great book, Thinking, Fast and Slow (New York: Farrar, Straus and Giroux, 2011) shows that humans use instinctive processes subject to many limitations (cognitive biases) as well as more considered thought. Cognitive biases make it hard for consumers to notice certain clauses that are likely to harm them. For further discussion of difficulties with notice to consumers, see the discussion of salience in the fourth part of this article.

15 Oren Bar-Gill, Seduction by Contract: Law, Economics, and Psychology in Consumer Markets (New York: Oxford University Press, 2013). 
contract cannot be guaranteed without a remedy available for anyone who suffers loss because of breach.

Consumers subject to fine print, even if we consider it part of a product and even if we think the product is properly priced in a market, still should not be held to alienate certain basic rights to redress grievances. Yet many prevalent boilerplate clauses used in the United States attempt to do just that. Clauses in widespread use include exculpatory (exclusion) clauses, arbitration clauses (which preclude both jury trial and aggregate relief), remote choice of forum/choice-of-law clauses, as well as others, such as a clause permitting unlimited modification by a firm and a clause curtailing the statute of limitations.

However society handles the issues raised by normative degradation in mass market "contractual" standardization, democratic degradation poses another and more basic issue. In my view, we will have to develop background non-waivable rules safeguarding the fundamental rights of civil society. These are the rules that forestall democratic degradation. Here, I am focusing particularly on the rights associated with the redress of grievances.

It remains to be seen whether judges, elected representatives, or other administrative bodies should be the branch of government making decisions about democratic degradation. The task of deciding whether a party is in violation of the unwaivable duty of good faith (or honesty or ethical behaviour) in performance of a contract is traditionally the task of a court. ${ }^{16}$ Courts could also take responsibility for evaluating a mass market standardized "contract" for democratic degradation. This task involves deciding whether a particular mass market deployment of clauses curtailing the redress of grievances amounts to democratic degradation, which should be disallowed in order to preserve the fundamental attributes of belonging to a civil society. Courts could take on this task by invoking the constitutional ideals of due process of law ${ }^{17}$ or by invoking the tort law relating to defective products. ${ }^{18}$ Courts would have to take into account the effect of the clause on civil society - on all recipients, not just on the one(s) complaining before the court.

This would be a deviation from the way contract cases are usually decided, under doctrines that focus on a deal between two individuals or entities. But mass market fine print is best understood not as a traditional contract involving willing agreement to a consensus ad idem. Given the realities of the marketplace and the normal way recipients treat fine print, mass market fine print is not amenable to reasonable case-by-case judgment about whether a given individual did or did not consent. (Unless we credit "as-if" notice as equivalent to "as-if" consent and say that those "as-ifs" amount to enforceable contractual obligation, but we are in the information society world and it would mean imposing this "asif' regime on millions of people. ${ }^{19}$ )

Furthermore, the evaluation of mass market waivers of basic rights is not amenable to judging on an individual basis whether the given individual had the power to consent or whether the right is not

16 See supra note 5.

17 Judith Resnik, "Diffusing Disputes: The Public in the Private of Arbitration, the Private in Courts, and the Erasure of Rights" (2015) 124 Yale LJ 2804.

18 See Margaret Jane Radin, "The Fiduciary State and Private Ordering" in Paul B Miller and Andrew S Gold, eds, Contract, Status, and Fiduciary Law (Oxford: Oxford University Press, 2017).

19 See the first part of this article. 
amenable to individual waiver - in other words, whether the right is market- inalienable. ${ }^{20}$ We are now outside the arena of contractual justification. Which rights are not amenable to individual waiver regardless of the existence or non-existence of consent by an individual - is not a matter for individual or case-by-case decision making.

So far, I have been suggesting that the core rights to the redress of grievances are basic to the existence of civil society and should not be waivable by individuals. Partly, I have limited myself to this suggestion because it is central to access to justice and because it seems obvious that the availability of the redress of grievances is basic to the maintenance of civil society, even without a more generalized theory of what kinds of rights are (or should be) market-inalienable. As well, partly I have limited myself to this suggestion because it seems to me too soon to develop a generalized theory applying to the content of fine print that is allegedly contractual. Perhaps other constitutional or rights under the Canadian Charter of Rights and Freedoms aside from access to justice and due process of law are (or should be) market- inalienable in the context of contemporary mass market standardized fine print. $^{21}$ Perhaps the right to privacy will also be among them. Certainly, the information society puts pressure on the ideals and realities of safeguarding personal privacy. Many people agree that Facebook's TOS leave much to be desired when it comes to users' privacy, but many also believe that there is nothing we can do about that. ${ }^{22}$ Meanwhile, concentrating on the redress of grievances seems a good place to start. Standardization and the possibilities engendered by the information society are undeniably useful and, in any case, here to stay, but we should develop new rules to safeguard the characteristics that we value as a civil society.

\section{THE RULE OF LAW}

\section{A. Boilerplate Rights Deletion and the Rule of Law}

In my previous writings about the problem of democratic degradation associated with mass market boilerplate, I have referred to the principles of the rule of law. ${ }^{23}$ So far in this article, I have not discussed this concept. It is a contested concept, and there are many versions of it and ways to argue about it. ${ }^{24}$ Nevertheless, the concept of the rule of law is helpful, I believe, to understand why it is important to declare pre-dispute remedy deletion off limits to private law re-arrangements of background rules when the remedy deletions are accomplished by mass market standardized fine print.

Rights deletion through the massive deployment of boilerplate undermines the rule of law because these "contracts" purport to privatize rights that must remain public. The enforcement of exchanges by private ordering (contract) is legitimate only within a state that underwrites a background legal infrastructure by

20 Market-inalienability refers to a right that is inalienable in the context of trade. See Margaret Jane Radin, Contested Commodities (Cambridge, MA: Harvard University Press 1996) 18; Margaret Jane Radin, "Market-Inalienability" (1987) 100 Harvard L Rev 1849.

21 Canadian Charter of Rights and Freedoms, Part 1 of the Constitution Act, 1982, being Schedule B to the Canada Act 1982 (UK), 1982, c 11.

22 Many contemporary scholars are seeking ways to protect privacy. See, eg, A Michael Froomkin, "Regulating Mass Surveillance as Privacy Pollution: Learning from Environmental Impact Statements" (2015) 2015 U Illinois L Rev 1713.

23 See, eg, Margaret Jane Radin, "Boilerplate: A Threat to the Rule of Law" in Lisa Austin \& Dennis Klimchuk, eds, Private Law and the Rule of Law (Oxford: Oxford University Press 2014) [Radin, "Boilerplate"].

24 Ibid; see also Margaret Jane Radin, "Reconsidering the Rule of Law" (1989) 69 Boston U L Rev 781. 
which the state decides which contracts are enforceable. That is, the state (through the courts) must decide which contracts are legitimately made under the rules of this background infrastructure. Enforcement is state coercion, by means of which an unwilling party is deprived of an entitlement (usually damages) that is redistributed to the other party. The rules of the background infrastructure exist to justify that coercion. Factions or powerful firms should not be able to change the rules to redistribute entitlements to themselves whenever they wish by a simple expedient such as the deployment of boilerplate. The rules of the background legal infrastructure must remain substantially within the care of the polity.

The boilerplate presumably could not permissibly say, for example, "this contract is only enforceable by the firm and not by the recipient." But by saying that the firm may modify the "contract" however and whenever it wants, or that the recipients' only remedy is arbitration, or in a faraway place, or sooner than the statute of limitation would have allowed, firms (at least in the United States) are using boilerplate to engage in privatization of the legal infrastructure of contracts. By undermining the feasibility of the remedy, firms that deploy boilerplate rights deletions are undermining the infrastructure of private law.

At least if the principle of equality before the law must be honoured in practice in order to say that a system observes the rule of law, all rights holders must have reasonable access to remedies. In other words, if the rule of law is to be of use in evaluating what a legal system should look like, the availability of legal redress of grievances must be taken as a basic principle. Thus, for a society to be recognized as being constituted in accordance with the rule of law, it should keep certain rights in the care of the polity and not allow them to degenerate into default rules changeable by firms through the deployment of mass market boilerplate. The rule of law at its most basic level requires that some rights not be privatized such that they can be curtailed and sometimes eradicated by firms.

\section{B. Notice and Salience for Consumers}

The rule of law might help us think about the principles governing decisions about which rights must remain permanently in the care of the polity. This in turn might help us think about which types of alleged "contracts" should in fact be evaluated under legal regimes other than contract law. The question of which rights should be permanently in the care of the polity, and under what circumstances they must be protected, invites controversy, but at least it will place debate in the proper place. Rather than continually arguing whether clicking "I agree" without reading the fine print does or does not amount to consent, legal decision makers should stop debating, first and primarily, about consent. There is a prior question: there must be some rights that cannot be waived by individuals on a massive basis even if in a particular case it looks as though consent was probable.

In previous writing, I have suggested some important criteria for determining that a right must remain in the care of the polity. The first criterion is that the right must be important to the collective wellbeing or constitutive of civil society - that is, without steadfast upholding of the right in practice, we would not have a civil society properly so called. In addition, however, I suggest that from this premise it follows that market-inalienability should be deployed only if a waiver of such a right is broadly disseminated, operating to waive such a right for a substantial portion of individuals in society, because it is the withdrawal of a right from a large portion of society that undermines civil society and the rule of 
law. ${ }^{25}$ I have also previously mentioned the significance of salience- the recognition by individuals of the importance of the right in question. Here, I want to elaborate the role of salience further to some extent.

Salience refers to the underlying importance to an individual of particular information. Most people probably know at some level that riding in a car with worn tires, or without buckling the seatbelt, greatly increases the risk of serious injury or death, yet often this information is not salient to a person who fails to act accordingly when driving. With respect to mass market boilerplate, the issue of salience prompts us to ask to what extent notice regimes are effective or to what extent particular information up-take in humans is generally possible or likely. Even if we accept the prevalent doctrine that tends to equate notice with consent, mass market boilerplate often depends on notice to the recipient for contract formation. The question is to what extent are we entitled to believe that notice exists, in the sense that information is actually received and understood by the individual? (Here I am omitting the doctrine that I have dubbed the "as-if" doctrine.) In the past few decades, there has been a revolution in the psychological understanding of human reaction to the provision of information and how it influences human choices. ${ }^{26}$ This revolution prompts consideration of to what extent we can now believe -if we ever could - that the provision of information that a right is being waived is enough to licence belief that the recipient of the fine print has actually received notice in the sense of becoming cognizant of the information.

Provisionally, I suggest that we can usefully think of three categories of salience:

Category 1: The information is of a type that is usually salient to the group of recipients that an entity desires to notify.

Category 2: The information is less salient to the desired group, but notice can be achieved by extra precautions, such as presenting information in visual modalities rather than in print.

Category 3: The information is almost never salient to the desired group of recipients.

For the recipients in Category 1, whether we speak in the language of contact or merely of disclosure, notice (if it is actual notice and not hypothetical) will succeed, even if presented in fine print. For example, the disclosure of copyright interference seems to work for people who care about their copyrights. ${ }^{27}$ For recipients in Category 2, where disclosure is somewhat impacted by cognitive biases, firms that wish to achieve notice would have to take precautions. A primary cognitive bias that a firm would need to counteract is the unconscious optimism bias ("It won't happen to me. I'll never need to exercise a legal remedy."). Another common bias to overcome is stickiness ("I've been OK so far and I

Radin, "Boilerplate," supra note 23.

See supra note 14.

In 2012, Instagram, a photo-sharing site owned by Facebook, posted a new set of terms of service. After serious complaints by its users, it had to withdraw a clause that seemed to give it the right to reproduce users' photos without their consent. See Alexander Eichler, "Instagram Terms of Service Change Sparks Revolt," Huffington Post (20 December 2012). 
don't want to change and do something different."). Some research shows that biases such as these can be counteracted by visual or oral notice rather than written notice. ${ }^{28}$

When attempted notice is in Category 3, however, the information is almost never salient. In such cases, there are attempted notifications that recipients can hardly ever take seriously even if presented visually or otherwise forcefully. It would be a good issue to investigate empirically, but I find it very plausible that the background availability of legal remedies is something we humans find very difficult to value ex ante (before we need them). We are generally psychologically programmed to think that bad things happen to other people, it seems, and many people (at least in the United States) routinely sign away the rights of their children as well as their own.

The fact that humans are not psychologically programmed to understand that they might need a legal remedy is of course only one reason to think that people should not be able to waive their legal remedies. There are more important reasons, based upon the basic political theory of democracy, why individuals ought not to be able to delete legal remedies for themselves and their children, because this result, when it becomes massive, is not consonant with civil society and the rule of law. Yet sticking with the threshold issue of salience in notice, we currently do not have as much data as we would like on this issue, but we know pretty well that fine print that is claimed to be notice even if one does not read it is not notice and neither is notice that we read but that is not salient to us.

Where are we now? It seems to me that it is not the case that all attempted restructurings of entitlements by notice are good, whether instituted by private law or public regulation, supposedly justified by the argument that they allow people to decide for themselves, instantiating freedom of choice. (We do not allow people to decide for themselves whether to buy cheaper, but likely contaminated, food.) Yet it is also not the case that all attempted restructuring of entitlements by notice are bad, whether instituted by private law or public regulation, supposedly justified by the argument that people cannot pay attention to them and cannot make choices that take them into account. (People may decide for themselves whether to purchase something "as-is" for less money.)

Answers to these questions depend upon what type of good and what type of notice we are talking about. Food content is amenable to notice (especially to those with life-threatening allergies); the presence of a balloon payment clause in a mortgage not so much; the deletion of legal remedies hardly at all. In this article, I have focused on the loss of remedies rather than on trying to take on the complexities of increased generality. Even without a more general theory, we can recognize that the deletion of remedies on a massive basis results in democratic degradation.

\section{POSTSCRIPT: A TALE OF TWO COMMON LAW INTERPRETATIONS}

To conclude this article, I offer a short and incomplete comparison between US and Canadian common law analysis of remedy curtailment by means of fine print. I think what this incomplete comparison tends to show is that jurisdictions may use the same doctrines and types of argument but that their use may result in a different legal landscape. Because contract as a common law subject stems from the law of England both in the United States and in Canada's common law provinces, there are many doctrines in common: among them, offer and acceptance, consideration, honesty or ethical behaviour in

28 See, eg, Christine Jolls, "Debiasing through Law and the First Amendment” (2015) 67 Stanford L Rev 1411. 
performance, equitable and legal remedies, and the role of adequate "notice" in freedom of contract. Yet when it comes to the adjudication of the enforceability of standardized form "contracts," although many of the words are the same, the meanings in practice seem to be different.

\section{A. Mass Market Arbitration Clauses}

The prevalence of mandatory pre-dispute arbitration clauses deployed against consumers is probably the most significant divergence between Canada and the United States. Arbitration as an alternative dispute resolution procedure exists in Canada, and Canadian courts look upon it favourably. Under the competence-competence principle, arbitration is in many ways of equal stature with court proceedings. ${ }^{29}$ Yet the Canadian courts have realized that forcing a consumer into arbitration that cancels the right to bring an action in court can in effect deprive the consumer of legal redress. ${ }^{30}$ The Supreme Court of Canada has declared that it is up to the provinces to decide whether mandatory arbitration clauses can be deployed against consumers, ${ }^{31}$ and Ontario, Quebec, and Alberta have legislated variously against permitting mandatory arbitration to be used against consumers.

In the United States, in contrast, mandatory pre-dispute arbitration clauses are massively deployed against consumers, employees, and businesses in the position of consumers. Unlike Canada, the US Constitution contains a supremacy clause that says that federal law must trump any state law that interferes with federal law. ${ }^{32}$ The recent US Supreme Court - that is, five of its nine members interpreted this constitutional clause to preclude states from trying to regulate arbitration clauses used against consumers. How did the five justices accomplish this interpretation? In 1925, the US Congress enacted a law - the Federal Arbitration Act - in order to permit firms, if they agreed in advance, to arbitrate their disputes rather than going through the more expensive procedure of litigation in court. ${ }^{33}$ The US Supreme Court interpreted this 1925 federal statute ever more expansively, to the point where states are prevented from trying to protect consumers against losing their rights to trial. Moreover, the federal right to contract for arbitration is now held to trump not just state rights but also other federal rights, such as antitrust laws or employment discrimination laws ${ }^{34}$ Thus, you will find that a large proportion of boilerplate "contracts" you receive in the United States will contain a mandatory arbitration clause.

What is wrong with using arbitration in consumer disputes? It is supposed to be cheaper and quicker, which is why companies like it and, in theory, why consumers should like it, too. But there are several reasons for consumers to dislike forced arbitration: first, the arbitrators are repeat players for the firms,

29 Dell Computer Corp v.Union des Consommateurs, [2007] 2 SCR 801, 2007 SCC 34 (Can LII).

30 Griffin v Dell Canada, Inc, 2010 ONCA 29, 98 OR (3d) 481.

31 Seidel $v$ TELUS Communications Inc, [2011] 1 SCR 531.

32 US Constitution, Article VI, clause 2: "The Constitution and the laws of the United States ... shall be the supreme law of the land...anything in the constitution or laws of any state to the contrary notwithstanding."

33 Federal Arbitration Act, Pub L 68-401, 43 Stat 883.

34 American Express Co v Italian Colors Restaurant, 133 S Ct 2304 (2013) [Italian Colors]. Due to the death of Justice Antonin Scalia in February 2016, the 5-Justice conservative activist majority that had continuously expanded the constitutional status of mandatory arbitration clauses was reduced to 4 , but it remains to be seen whether any changes will be forthcoming when a new Justice is seated. 
and it is at least widely suspected that they rule in favour of the firm most of the time; ${ }^{35}$ second, arbitration is private and secret, so that if a firm were to lose a waiver case to a consumer, it could still deploy the same waiver with every other consumer; third, arbitration creates no precedent, so that even if Consumer A wins an arbitration case and succeeds in disallowing a waiver, the firm can still deploy the same arbitration clause against Consumers B through Z; and, fourth, as interpreted by the US Supreme Court, arbitration must be strictly between the individual and the firm, so aggregative actions are prohibited. This means that many injuries - those that depend on aggregative actions for redress just cannot be remedied. The US Supreme Court, in effect, said that it is just too bad. ${ }^{36}$

Are US consumers ever able to litigate and disqualify a firm from using its arbitration clause? There are public interest firms and organizations trying to help consumers do this, and there are occasional victories. ${ }^{37}$ Sometimes, for example, the firm has changed its boilerplate so often that it cannot identify which version the consumer supposedly "agreed" to. Or sometimes the person that received the boilerplate is not the person who is supposed to be bound. But, on the whole, it seems that massive numbers of consumers are being deprived of access to jury trial and to aggregative remedies where otherwise ongoing wrong to a substantial number of people would be uncorrectable. This is not the situation in Canada. So far, at least, it seems to be understood in Canadian common law jurisprudence that arbitration can be a good alternative to litigation when used judiciously and also understood that it can deprive consumers of remedy when it oversteps appropriate bounds.

\section{B. Exclusion or Exculpatory Clauses}

Exculpatory or exclusion clauses, waiving the liability of one party to the other, are often used in business-to-business dealings. It is often said that "equal bargaining power" between the parties will allow for risk shifting. Perhaps it is better to characterize this as equal status for negotiation. Such equal status and the possibility of negotiation is present in many business-to-business dealings but not all of them. (Some businesses are in the position of a consumer vis-à-vis another business.) In circumstances of equal status of negotiation, the exclusion or exculpatory clause resolves to determine which party is supposed to buy insurance (or self-insure). If Firm A excludes liability, then Firm B is responsible for its own insurance, and in the equality of negotiation situation, this will affect the price and perhaps other parameters of the agreement as well.

These exculpatory or exclusion clauses are also used in business-to-consumer dealings. Here, there is likely no equal status of negotiation, and it usually makes little sense to imagine that the consumer should buy her own insurance (even if the consumer realized that was necessary). In most cases of exculpatory clauses deployed against consumers, the firm is the best cost avoider. That means that the firm, and not the consumer, can avoid losses by screening its employees, maintaining its equipment, and

35 See David Horton \& Andrea Cann Chandrasekher, "After the Revolution: An Empirical Study of Consumer Arbitration," UC Davis Legal Studies Research Paper (2015) at 66 (disputing earlier research claiming arbitrators are employed by firms and biased in their favour but concluding that "high level and super repeat playing companies perform particularly well in arbitration"). See also Resnik, supra note 17 at 2853 (describing how arbitration organizations are structured so that it is impossible for us to know and observe what they and their members are doing).

36 See Italian Colors, supra note 34 (dissenting opinion of Justice Elena Kagan).

37 See, eg, Public Justice <http://www.publicjustice.net>; see also Alliance for Justice <http://www.afj.org>, which has produced a film entitled Lost in the Fine Print (2014) 
so on. ${ }^{38}$ Exculpation for a firm's own negligence in a business-to-consumer contract violates a primary duty of the state to recognize and protect background rights. The reason why such rights of redress should be non-waivable, and not mere default rules subject to waiver, is that the consumer cannot check on all of the employees with whom it deals nor check on the firm's equipment maintenance, and so on. The consumer, in particular, cannot do this when she would have to do it with every firm she deals with - and this is how common these clauses are in the United States. ${ }^{39}$

Many states in the United States are routinely enforcing boilerplate clauses that exculpate a firm for its own negligence (meaning the firm will not be liable in tort for its own substandard practices that cause injury to someone). Moreover, some states in the United States are going further and holding that parents can exculpate a firm for harming their children in addition to themselves. ${ }^{40}$ Many states still disallow such waivers, but it is the business of lawyers to push the envelope. So, today, when a parent enrols a child in a recreation facility or a summer camp, the parent will be asked to sign or click "I agree" to boilerplate including a waiver excusing the firm for anything it does (or fails to do) that hurts his or her child. The same thing happens to people who want to find a nursing home for their elderly and sick parent, people who want to use recreational or training facilities, and working people who want to access day care facilities for their children.

The need to safeguard the redress of grievances with respect to necessary background rights calls into question the many boilerplate clauses prevalent in the United States that, in practice, make a viable remedy unattainable for large numbers of people. Of particular concern to me is the gathering trend in the United States - and to a lesser extent in Canada - allowing boilerplate to waive liability for harm caused by negligence. In Loychuk v Cougar Mountain Adventures Ltd, customers of a zip-lining facility were injured. ${ }^{41}$ The plaintiff alleged that the facility's employees caused the accident by releasing a second zip-liner down the wire before the previous one had safely arrived at the end point. The plaintiffs had signed a release agreement that stated (in pertinent part):

[I agree] to waive any and all claims that I have or may in the future have against the releasees and to release the releasees from any and all liability for any loss, damage, expense or injury, including death, that I may suffer or that my next of kin may suffer, as

38 I take note that some business advocates do not believe that any legal regime to deter negligent behaviour of firms is necessary, because the threat of harm to a firm's reputation will suffice to keep it from mistreating those who deal with it. And some believe that legal deterrence measures do not actually operate to deter negligence or other wrongdoing. But at least if we believe deterrence is necessary and efficacious, such degeneration of background rules into default rules allows firms to be irresponsible (and perhaps, in a competitive market, forces them to be); and leaves recipients on their own for avoiding harms that may threaten them in their everyday lives.

39 Note that all of this exculpation that is going on in the United States through boilerplate relates to service providers, not to products. In the United States, contracts for the sale of goods are covered by the Uniform Commercial Code, a model statute that has been enacted in every state (with some differences). This statute says that exculpation for the seller's own negligence is prima facie unconscionable if it injures a consumer. UCC 2-719(3): "Limitation of consequential damages for injury to the person in the case of consumer goods is prima facie unconscionable." But there is no such law for services.

40 See Colorado Statute 13-22-107 http://www.leg.state.co.us/2003a/pubhome.nsf $>$; Kelly $v$ United States, 809 F Supp 2d 429 (EDNC 2011); BJ's Wholesale Club v Rosen (MD, 7 November 2013).

412012 BCCA 122. 
a result of my participation [in these activities], due to any cause whatsoever, including negligence, breach of contract, or any statutory or other duty of care.

The plaintiff, a law student, had signed the clause waiving liability, believing that such clauses are unenforceable. (Perhaps her professor thought that they were, at least against a consumer.) Meanwhile, the defendant confessed negligence. One might conjecture that the defendant did so in order to avoid the risk of being held on the facts, after the presentation of evidence, to be guilty of gross negligence, for which the boilerplate disclaimer would be less likely to have exonerated it. The court held that the disclaimer was valid because it was clear that the plaintiff had notice of it, thus satisfying one prong of unconscionability doctrine, relating to whether or not there was deception or otherwise lack of consent. The doctrine of unconscionability also hinges on whether there was serious inequality of bargaining power or some indication of severe unfairness such as extreme over-pricing. But the court in Loychuk thought that because the doctrine of unconscionability in order to invalidate a clause requires both aspects of unconscionability, its finding that consent existed relieved it of looking at the issue of unfairness or other substantive issues. ${ }^{42}$ Nor was the substantive issue reached under an analysis of possible voidness against public policy.

The Loychuk decision was criticized by many in Canada. ${ }^{43}$ It would have been perfectly routine in many states of the United States, where it almost goes without saying that any recreational activity that may be dangerous is undertaken entirely at the risk of the participant. In fact, this is often stated as a general rule. Yet it seems obvious that negligence in maintaining a ski resort, for example, is a risk that should not be transferred to the participant because the management, and not the participant, is the only party that can realistically be responsible for matters such as clearing the trails of buried debris and rocks or for hiring competent and experienced personnel when it comes to advice about trails or to coaching children. Even for businesses offering risky activities, the business is often the best cost avoider for many types of accidents.

Although exculpatory clauses are more prevalent in the United States than in Canada, at least for now in the United States, even if the wording of the clause is all-inclusive, the courts enforce it only so far as precluding an action for negligence. It is a worry, however, that the all-encompassing wording in many

42 I believe that this two-pronged view of unconscionability is borrowed from a widely adopted American approach. In this American approach, unconscionability is often not a winner for consumers. The court is allowed to take into account what terms are used by other businesses, so industry-wide onerous practices are more likely to be sustained. Also, the doctrine requires both "procedural" and "substantive" unconscionability to be found in order to rule for the consumer. "Procedural" means, roughly, does the court think there was adequate consent or agreement? If a court judges the consumer to have consented, it will not have to investigate whether the contract is substantively bad or, indeed, whether the consumer has signed away a right that is not subject to consumer choice because it is permanently in the care of the polity (see section IV in this article). The apparent adoption by the Loychuk court of this two-pronged cumulative view may have been one reason the decision was widely criticized.

43 The Loychuk court cited Tercon Contractors Ltd v British Columbia, 2010 SCC 4, for the proposition that a party seeking to void an exclusion clause not unconscionable when made would have to show abuse of freedom of contract that outweighs the very strong public interest in contract enforcement. Tercon involved a specifically negotiated contract between commercial parties, where it would be possible to construe an exclusion clause as related to contractual choice (see the second section of this article). Critics of the Loychuk decision could argue, as I do, that freedom of contract is attenuated in business-to-consumer mass market boilerplate and that it is almost never the case that a consumer bargained for some other benefit in return for accepting an exclusion clause. 
of these clauses (if anyone does read them) deters injured parties from bringing suit. Moreover, even if the court enforces a negligence waiver but not a gross-negligence waiver, the plaintiff will have to produce evidence and argue her case about whether the negligence that injured her was gross or not.

In the United States at present, blanket exculpatory clauses are showing up in conjunction with all kinds of services: in activities that parents need or want for their children, in nursing homes, and in fitness facilities, even in music camps. Of course, most of the time, we sign these things without reading them because we need the service. Modern contract doctrine has it that whatever document I sign, whether or not I read it or understand it, binds me to its terms, unless my signature is coerced. It is now worth considering whether in some instances, such as enrolling a child in school or daycare or a disabled parent in a nursing home, the signature should be considered coerced. The choice between keeping a child at home all the time or else signing away her rights to legal redress is the type of narrow choice that could normally be considered unfair and coercive. ${ }^{44}$ Of course, most of the time, we sign these things without reading them or click "I agree" without reading them, because we need the service. So even the idea that we are being given a choice that is coercive is most often fictional. Instead, exclusion clauses have become a mass market phenomenon rearranging our legal rights to redress. In practice, we often have very little to say about such loss of rights. Even if we can see the information, we (often) do not understand its meaning, and even if we do see and understand it, there (often) is not anything we can do about it.

\section{Notice}

As I have mentioned earlier, it seems outdated for various reasons to consider mere notice of a waiver to be a "contract," even if the recipient can see it and even if the recipient can understand it once seen. Nevertheless, both the United States and Canada adhere to this well-settled traditional doctrine. But their adherence to the doctrine is not identical in practice. Canadian courts have been mostly more willing to consider how reasonable the notice is, and reasonableness has also depended on the fairness and reasonableness of the conditions. The famous Canadian case of Tilden Rent-a-Car v Clendenning stands for the proposition that it is especially important to draw specific attention to an onerous condition if a recipient is in a situation in which she has no time to read and understand how the condition might affect her. ${ }^{45}$

This is not the type of rhetoric usually found in US cases. US courts use the same discourse of notice and sometimes discourse of inequality of bargaining power. But US cases allow more onerous boilerplate to be enforced. In the United States, it is often held acceptable for terms to come after a purchase is made, when there would have been no opportunity to see the terms beforehand. The US Supreme Court in Carnival Cruise Lines $v$ Shute reviewed a case in which the plaintiffs from the state of

44 Coercion is a philosophical topic of great depth and complexity, which I do not explore in this article. The view of coercion that I favour regards coercion as present when someone puts a party to a choice that she has a moral right not to be put to. "Your money or your life" is a standard example. The victim is freely choosing to hand over her wallet to save her life, yet many thinkers on the topic of coercion would say the victim is coerced because she has a moral background right not to be put to that choice. Under this view of coercion, it seems that in today's society, parents should have a moral right to acquire services for their children without giving up their legal remedies in case their child is injured by the provider's negligence (or worse).

45 Tilden Rent-a-Car Co v Clendenning (1978) 18 OR (2d) 601, 4 BL 50, 83 DLR (3d), 400 (CA) Although I believe that this 1978 case is still a staple for law students, it must be noted that it has been subject to increasing controversy. 
Washington were held to a forum selection clause limiting their cause of action to the state of Florida, which was the defendant's corporate domicile. ${ }^{46}$ The clause appeared in small print on the last page of their ticket, which they received only after they paid for it, and the payment was non-refundable. It seemed clear that the plaintiffs had no opportunity to see the clause before purchasing the ticket. For some reason that was not made clear in the US Supreme Court opinion, the case was litigated under the stipulation that the plaintiffs had notice of the clause and had agreed to it. (Possibly, the legal strategy was to focus on the question whether the clause would be fundamentally unfair even with consent.) In addition, the case was decided under admiralty law because the injury happened at sea, so the court did not engage the constitutional standards of due process, which are usually stated as fair play and substantial justice.

In deciding for the defendant, the US Supreme Court majority did not address what would have happened without actual consent. It upheld the defendant's onerous choice of forum clause for various reasons, among them, the idea that "it stands to reason" that the firm will save money by litigating at home and will pass on those savings to consumers. ${ }^{47}$ This reasoning was very weak, to say the least, because whether or not firms pass on savings or simply pocket the extra money depends on complex empirical factors. Furthermore, this weak reasoning contains a dubious normative assumption - the idea that the right to redress can be "condemned" by the firm when compensation is paid.

The lower federal courts in the United States adopted the weak reasoning of Carnival Cruise and extended it, erasing the underlying assumption that consent was present and ignoring the posture in admiralty rather than the constitutional law of due process. Thus, the courts in the United States accepted the idea that notice of an onerous clause can come later, after the main transaction. In a famous case decided by the Court of Appeal for the Seventh Circuit, Hill v Gateway, the plaintiffs wished to bring a class action suit against the computer company because of a lack of satisfaction with the product or its customer support, but a form contract that they received in the box when the computer was delivered limited redress to arbitration. ${ }^{48}$ The plaintiffs challenged the arbitration clause on the basis that they did not have any opportunity to see it until after the computer was purchased and delivered, but they lost this challenge. This case is now routinely cited for upholding the practice of "PNTL [pay now, terms later]" contracts. In the United States, it is most often good enough to notify consumers later and expect the consumer to send the product back for a refund if she does not like the terms.

In Canada, it seems that actual notice is still valued. My view, as the reader knows, is that merely knowing some informational content is not the same as actually agreeing to that informational content. So the common law, in its objective manifestation, did slip from actual agreement to mere actual notice. Canadian cases seem to say that if it was unlikely that the recipient would have seen the clause perhaps only if the clause is particularly onerous - then notice is not properly given. But in the United States, this slippage has gone much farther. US cases rarely will take into account the situation of the recipient in his or her ability to take note of the clause and what it means. If they did, they might be less

46 Carnival Cruise Lines v Shute, 499 US 585 (1991) [Carnival Cruise]; Linda S Mullenix, “Carnival Cruise Lines v. Shute: The Titanic of Worst Decisions" (2012) 12 U Nevada LJ 549.

$47 \quad$ Ibid at 594.

48 Hill v Gateway 2000, Inc, 105 F3d 1147 ( $7^{\text {th }}$ Cir 1997). In widely cited case of ProCD veidenberg, 86 F3d 1447 at 1451, which was relied on in Hill v Gateway, the 7th Circuit judge cited Carnival Cruise, supra note 46, as an unqualified holding that "[t]o use the ticket is to accept the terms, even terms that in retrospect are disadvantageous." 
likely to endorse "PNTL." In sum, in spite of the shared heritage of Canada and the United States in the common law of contract, I think that the United States is much more likely to enforce boilerplate waivers of rights than is Canada. So far, the United States has used "contracts" to undermine access to justice more than Canada. 